\title{
Pawel Piątkowski
}

Uniwersytet w Białymstoku

e-mail: p.piatkowski@uwb.edu.pl

\section{DEUG PUBLICZNY I NIERÓWNOWAGA BUDŻETOWA W KRAJACH UNII EUROPEJSKIEJ. OCENA EFEKTÓW REFORMY PAKTU STABILNOŚCI I WZROSTU Z WYKORZYSTANIEM METODY TOPSIS}

\section{PUBLIC DEBT AND BUDGET DEFICIT \\ IN THE EUROPEAN UNION. EVALUATION \\ OF REFORM OF STABILITY AND GROWTH PACT EFFECTS USING TOPSIS METHOD}

DOI: $10.15611 /$ pn.2018.528.15

JEL Classification: H62, H63

Streszczenie: Kryzys zadłużeniowy w Unii Europejskiej uwypuklił niedoskonałości rozwiązań zawartych w Traktacie z Maastricht w odniesieniu do koordynacji polityki fiskalnej. Były one znane, lecz w 2010 roku uświadomiono sobie konsekwencje tych niedoskonałości. W obliczu możliwego rozpadu strefy euro wdrożono rozwiązania, które miały poprawić koordynację polityki fiskalnej, ustabilizować sytuację budżetową i docelowo obniżyć poziom długu publicznego. Celem artykułu jest ocena, czy wprowadzenie powyższych rozwiązań wpłynęło na poprawę sytuacji w krajach strefy euro. Do analizy przyjęto lata 2010-2017. Wykorzystano metodę TOPSIS z grupy metod wielowymiarowej analizy porównawczej. Otrzymane wyniki wskazują, że sytuacja w zakresie zadłużenia i nierównowagi budżetowej w Unii Europejskiej nie poprawiła się w znaczącym stopniu, a w całym okresie wahała się. W związku z tym należy mieć wątpliwości odnośnie do skuteczności wdrożonych rozwiązań.

Słowa kluczowe: dług publiczny, deficyt budżetowy, metoda TOPSIS.

Summary: Debt crisis emphasized not efficient coordination in the area of fiscal policy in the European Union. It was a well known problem but it has not been solved. Debt problems of Greece showed how important it was to be more effective in the area of public debt. The European Union prepared new law which was to strenghten fiscal coordination in Euro-zone. Moreover, competencies of the European Commission increased in the area of reporting and coordinating of fiscal policy. The aim of the article is to check if the results of the new law are satisfying. Analysed period were the years 2010-2017. TOPSIS method was used in the research. As a result, it can be noticed that the European Union did not do any progress in the area of fiscal policy coordination and public debt decrease.

Keywords: public debt, budget deficit, TOPSIS method. 


\section{Wstęp}

W 2010 roku Grecja stanęła w obliczu kryzysu zadłużeniowego. Nie był to pierwszy przypadek, gdy państwo nie było w stanie obsługiwać swoich nadmiernych zobowiązań. Nietypowy był fakt, że dotyczyło to kraju rozwiniętego. Co więcej, po raz pierwszy niewypłacalne państwo należało do strefy euro, a więc jego problemy dotknęły całej Unii Gospodarczej i Walutowej. Konieczne stało się wypracowanie rozwiązań pozwalających przezwyciężyć kryzys i jednocześnie zachować jedność Wspólnoty. Zaproponowane i wdrożone rozwiązania miały na celu przezwyciężenie problemów oraz zapobieżenie im w przyszłości. Celem niniejszego opracowania jest ocena, w jakim stopniu zastosowane w Unii Europejskiej rozwiązania dyscyplinujące i motywujące kraje członkowskie do poprawy sytuacji budżetowej przyczyniły się do osiągnięcia zakładanych wskaźników pod względem zadłużenia i niezrównoważenia budżetów. Badaniem objęto lata 2010-2017. Do analizy wykorzystano jedną z metod wielowymiarowej analizy porównawczej - metodę TOPSIS. Skonstruowano wskaźnik syntetyczny oceniający zadłużenia publiczne i nierównowagę budżetową w sposób szerszy niż tylko przez pryzmat długu i deficytu.

\section{Koncepcje rozwiązań stabilizujących i ograniczających poziom zadłużenia}

Problem przywracania i utrzymywania równowagi budżetowej oraz stabilności zadłużenia jest często poruszany w literaturze ekonomicznej. Kryzys zadłużeniowy ponownie zwrócił uwagę na ten element zarządzania długiem publicznym. Wśród przedstawianych w literaturze rozwiązań prowadzących do stabilizacji lub redukcji długu publicznego można wymienić kilka możliwości.

Pierwszą z nich jest konsolidacja fiskalna. OECD definiuje ją jako konkretne działania z zakresu polityki gospodarczej mające na celu ograniczenie deficytu budżetowego i długu publicznego [OECD 2011, s. 17]. Nie precyzuje więc, jakiego typu działania powinny być podjęte. Precyzyjnie jest za to określony ich cel. Z kolei A. Rzońca definiuje ją jako taką podwyżkę podatków, która owocuje stabilizacją poziomu zadłużenia [Rzońca 2004]. Wydaje się to jednak dość jednostronne rozwiązanie. Inni autorzy wskazują bowiem, że częstą metodą jest ograniczanie wydatków lub tzw. wyrastanie z długu dzięki dynamizacji wzrostu gospodarczego (zob. np. [Postuła 2014, s. 29]). Badania takich autorów, jak A. Fatás i L.H. Summers [2018], C. Nickel, P. Rother i L. Zimmermann [2010] czy A.F. Alesina, C.A. Favero i F. Giavazzi [2012] dowodzą, że o wiele skuteczniejszą drogą niż zwiększanie dochodów są ograniczenia w zakresie wydatków. Nakładanie dodatkowych podatków w okresie kryzysu powoduje duży opór społeczny. Wpływa również niekorzystnie na poziom popytu w gospodarce. Dodatkowo daje pokusę podniesienia wydatków w kolejnych okresach. Obniżanie wydatków również nie jest popularne, jednak daje 
trwalsze efekty - wymaga bowiem reform strukturalnych, które owocują wyraźną poprawą sytuacji finansów publicznych [Yang, Fidrmuc, Ghosh 2015]. W literaturze nie ma również jednomyślności w zakresie wpływu działań fiskalnych na tempo wzrostu gospodarczego. Część badań, np. Fatása i Summersa [2018] jednoznacznie wskazuje na negatywny wpływ konsolidacji fiskalnej podejmowanej w okresie kryzysu na tempo wzrostu gospodarczego. Z kolei A. Rzońca [2007] czy A.P. Balcerzak, M.B. Pietrzak i E. Rogalska [2014] wskazują na przypadki występowania niekeynesowskich efektów w postaci wzrostu tempa gospodarczego mimo wdrażanej konsolidacji fiskalnej. Sprzeczność obu spojrzeń powoduje, że trudno przewidzieć skutki podjęcia konsolidacji fiskalnej.

Drugą możliwością w zakresie naprawy finansów publicznych są tzw. dostosowania fiskalne (fiscal adjustment). Pojęcie to jest w różny sposób definiowane w literaturze. W wąskim rozumieniu jest utożsamiane $\mathrm{z}$ konsolidacją fiskalną. Jednak w większości przypadków jest definiowane szerzej. Na przykład Międzynarodowy Fundusz Walutowy do dostosowań fiskalnych zalicza działania w zakresie polityki fiskalnej zmierzające do zapewnienia trwałego i zrównoważonego wzrostu gospodarki. Jako przykłady działań wymienia tu dostosowania w zakresie kształtu polityki fiskalnej i wzmocnienie instytucji fiskalnych. Kierunek działań i instrumenty powinny być, według MFW, dobrane do sytuacji konkretnego kraju [Daniel i in. Van Rijckeghem 2006, vii]. Jak dowodzą Baldacci, Gupta i Mulas-Granados [2015], efekty dostosowań fiskalnych są znacznie korzystniejsze dla wzrostu gospodarczego niż te uzyskane drogą konsolidacji fiskalnej. Przede wszystkim w średnim okresie pozwalają na uzyskanie wyższego wzrostu gospodarczego dzięki odpowiedniemu zastosowaniu mieszanego podejścia do polityki fiskalnej. Wskazują na przykład na potrzebę cięcia wydatków, które nie są priorytetowe, oraz ochronę inwestycji prowzrostowych. Jednocześnie powinny im towarzyszyć odpowiednio dobrane działania o charakterze dochodowym, które nie będą miały negatywnego wpływu na konsumpcję i rynek pracy, a skupią się na likwidacji nieefektywności i nadużyć (np. likwidacja preferencji, obniżonych stawek podatków, wyższe opodatkowanie majątku zamiast pracy). Tak więc dostosowania fiskalne wydają się właściwym kierunkiem reform finansów publicznych.

Trzecią możliwość poprawy sytuacji fiskalnej stanowi wzrost przejrzystości działań rządu w zakresie długu publicznego i polityki budżetowej oraz powołanie niezależnych instytucji fiskalnych. Stanowi to w pewnym stopniu przeniesienie wzorców z polityki pieniężnej, w której reputacja oparta na przejrzystości działań i niezależności stała się podstawą skuteczności; również w zakresie zarządzania długiem publicznym właściwa komunikacja z inwestorami jest istotnym elementem budowania zaufania. W jej ramach podstawą jest przedstawienie kompleksowej strategii zarządzania długiem i jego przyrostu. Istotne jest również czytelne i uczciwe przedstawianie rezultatów działania. Jak dowodzą badania J.E. Alty i D.D. Lassena [2006], przejrzystość finansów publicznych wyraźnie wpływa na obniżenie poziomu deficytu i zadłużenia. Autorzy ci wskazali również, że poprawa przejrzystości 
finansów publicznych i zarządzania długiem jest istotnym elementem poprawy stanu finansów publicznych. Z kolei U.S. Das i inni [2010, s. 21] dowodzą, że przejrzystość polityki fiskalnej ma duże znaczenie dla dobrego skoordynowania z działania$\mathrm{mi}$ w ramach polityki pieniężnej. Operują one bowiem instrumentami finansowymi na tym samym rynku finansowym i połączenie ich wzmacnia skuteczność tych dziedzin polityki. Tak więc działania zmierzające do możliwie największej transparentności rządu ułatwiają prowadzenie polityki fiskalnej i skłaniają do preferowania działań ograniczających poziom deficytu budżetowego. Dzięki temu cena pieniądza pożyczanego przez sektor publiczny obniża się, a to dodatkowo poprawia kondycję sektora.

Czwartą możliwością oddziaływania na stabilność finansów publicznych jest tworzenie niezależnych instytucji fiskalnych. Mają one duże znaczenie w skuteczności polityki fiskalnej, gdyż, jak wykazali J. von Hagen i G. Wolff [2006], im ściślejsze są ograniczenia ilościowe, tym większa jest pokusa stosowania kreatywnej księgowości. Dlatego też decyzje z zakresu polityki fiskalnej i zarządzania długiem publicznym warto uniezależnić od cyklu politycznego. Niezależne instytucje mogą mieć charakter ciał doradczych, opiniujących, zatwierdzających lub nawet podejmujących niezależne decyzje [Maltritz, Wüste 2015]. Takie rozwiązania również zostały zaczerpnięte z polityki pieniężnej. Jednak większość rządów woli nie pozbawiać się uprawnień do zaciągania długu i decydowania o deficycie budżetowym. $\mathrm{Z}$ drugiej strony kraje decydujące się na utworzenie np. rad fiskalnych są postrzegane jako bardziej wiarygodne, a to znajduje odzwierciedlenie w cenie pozyskiwanego na rynku pieniądza. Jak wskazuje G. Kopits [2011], niezależne instytucje fiskalne są wciąż nowym zjawiskiem, przykładów jest mało, lecz wśród istniejących można znaleźć przykłady skutecznych instytucji.

Piątą możliwość stanowią reguły fiskalne, w tym złota reguła fiskalna czy reguły zrównoważonego budżetu (balanced budget rules - BBRs). Reguły uniemożliwiające wystąpienie deficytu są najbardziej definitywnym rozwiązaniem, gdyż część autorów dowodzi, że hamują wzrost gospodarczy. W związku z tym zrównoważenie budżetu i stopniowe spłacanie zadłużenia publicznego są rzadko spotykane na szczeblu rządowym, lecz na szczeblu samorządowym często stosowane i dobrze się sprawdzają. M. Groneck [2010] wskazuje przykłady badań, które różnie oceniają funkcjonowanie reguł fiskalnych, w tym zrównoważenia budżetów. Część tych badań jednoznacznie wskazuje na spowolnienie tempa wzrostu gospodarczego, podczas gdy inne wskazują na ich pozytywne skutki. Wyniki analiz przeprowadzonych przez Gronecka wskazują na pozytywne efekty wprowadzania reguł fiskalnych, a przede wszystkim złotej reguły. Potwierdza to w swoich badaniach również J.A. Stone [2016]. Wprowadzenie zrównoważonego budżetu może być konieczne ze względu na utratę zaufania inwestorów lub wysokie oprocentowanie obligacji skarbowych. Zrównoważenie budżetu ogranicza wydatki rządu w krótkim okresie i dlatego nie jest popularne z punktu widzenia cyklu wyborczego. W długim okresie jednak oszczędności z tytułu niższych kosztów obsługi długu publicznego zrekom- 
pensują ubytek w wydatkach. Dlatego też niewiele jest przykładów państw, które w chwili obecnej podejmują świadomie taką decyzję. Na przykład Wielka Brytania podjęła działania zmierzające do wprowadzenia zasady zrównoważenia budżetu, jednak wciąż nie jest to warunkiem prawnym.

Przedstawione powyżej rozwiązania nie wyczerpują w pełni dostępnych możliwości. Stanowią jednak przykłady rozwiązań pozwalających stopniowo naprawiać finanse publiczne w krajach, w których wystąpiły problemy z zadłużeniem.

\section{Kryzys zadłużeniowy w Unii Europejskiej i podjęte dzialania zaradcze}

Tworząc Unię Walutową i Gospodarczą, zapewniono pełną koordynację polityki pieniężnej poprzez przekazanie jej prowadzenia Europejskiemu Bankowi Centralnemu. Nie zdecydowano się jednak na taką integrację w przypadku polityki fiskalnej. Zdawano sobie sprawę, że może to mieć negatywne konsekwencje. W związku z tym przewidziano mechanizmy zapewnienia stabilności fiskalnej państw wchodzących w skład strefy euro. W Traktacie z Maastricht wprowadzono ograniczenie wysokości długu publicznego (do 60\% PKB) oraz deficytu budżetowego (do 3\% PKB). Niestety już w momencie wprowadzenia do obiegu euro trzy z krajów nie spełniały kryteriów. Stanowiło to niebezpieczny precedens. Wprowadzone mechanizmy egzekwowania przestrzegania ograniczeń były nieskuteczne, co wynikało z ich konstrukcji i uzależnienia od decyzji politycznych. Świadomość tych niedoskonałości nie skłoniła państw Wspólnoty do zmiany przepisów. Dlatego też w okresie kryzysu gospodarczego 2008-2010 dług publiczny i deficyt budżetowy wielu państw Unii Europejskiej wzrosły znacznie powyżej dopuszczalnych poziomów. Dopiero jednak kryzys zadłużeniowy, wywołany problemami Grecji, a potem Irlandii, Hiszpanii, Portugalii i Cypru, spowodowały, że podjęto działania zmierzające do wprowadzenia mechanizmów zabezpieczających przed nadmierną nierównowagą fiskalną i gospodarczą.

Pierwsze decyzje miały charakter doraźny i dotyczyły stworzenia mechanizmu finansowego pozwalającego udzielić pomocy krajom w trudnej sytuacji gospodarczej. W ich wyniku powstały: Europejski Mechanizm Stabilizacji Finansowej i Europejski Instrument Stabilności Finansowej. Miały one charakter tymczasowy i pozwalały na doraźną pomoc. Postanowiono jednak stworzyć docelowy instrument, będący wstępem do głębszej integracji gospodarczej. W wyniku tego 11 lipca 2011 roku powołano do życia Europejski Mechanizm Finansowy (European Stability Mechanism - ESM). Jest to międzynarodowa instytucja finansowa dysponująca łącznie funduszem 700 mld euro, przeznaczonym na doraźną pomoc krajom strefy euro przechodzącym przejściowe trudności. Już przy tworzeniu tego mechanizmu pojawił się sygnał, że restrykcyjne podejście, planowane w pierwotnej wersji, nie zostanie utrzymane. Planowano, że udzielenie pomocy będzie uzależnione od przedstawienia i przyjęcia restrykcyjnego pakietu oszczędnościowego, który pozwoli pokonać trud- 
ności. Już w kolejnym roku uchwalono złagodzone zasady, dopuszczające udzielenie pomocy bez takiego programu (również w formie doraźnej). Tak więc funkcje ostrożnościowa i prewencyjna zostały znacząco ograniczone [Trzcińska 2013].

Kolejnym rozwiązaniem wprowadzonym przez Unię Europejską był tzw. sześciopak. Obejmował on 5 rozporządzeń i 1 dyrektywę ${ }^{1} \mathrm{w}$ sprawie:

- skutecznego egzekwowania nadzoru budżetowego w strefie euro,

- przyspieszenia i wyjaśnienia procedury nadmiernego deficytu,

- wzmocnienia nadzoru pozycji budżetowych oraz nadzoru i koordynacji dziedzin polityki gospodarczej,

- wymagań dla ram budżetowych państw członkowskich,

- zapobiegania zakłóceniom równowagi makroekonomicznej i ich korygowania,

- środków egzekwowania korekty nadmiernych zakłóceń równowagi makroekonomicznej w strefie euro,

Przepisy te zmierzały do zwiększenia nadzoru nad narodowymi politykami fiskalnymi, wzrostu przejrzystości prowadzonych operacji finansowych, wprowadzenia sankcji za nieprzestrzeganie zasad lub niezastosowanie się do reguł, doprecyzowano procedurę nadmiernego deficytu. Ustanowiono wspólne ramy budżetowe dla krajów Unii, które mają na celu ograniczanie wzrostu wydatków. Ponadto wprowadzono procedury nadzoru i korygowania nierównowag makroekonomicznych będących podstawą wystąpienia kryzysów finansowych.

Jednym z istotnych elementów sześciopaku było wprowadzenie procedury semestru europejskiego. To procedura (trwająca około pół roku), zgodnie z którą Komisja Europejska monitoruje sytuację gospodarczą w państwach Unii. Na podstawie wyników oceny formułuje cele i zalecenia dla poszczególnych krajów, w ramach których ma być zachowana stabilność gospodarek, poprawiona sytuacja gospodarcza oraz wzmocniona konwergencja. Zalecenia te są dyskutowane na forum Unii i po kolejnych rundach przyjmowane. Wówczas kraje UE mają kolejne pół roku na wdrożenie ich w swoich budżetach na kolejne lata.

W 2013 roku wprowadzono również tzw. dwupak. Są to dwa rozporządzenia ${ }^{2}$ dotyczące:

1) wzmocnienia nadzoru gospodarczego i budżetowego nad państwami członkowskimi należącymi do strefy euro dotkniętymi lub zagrożonymi poważnymi trudnościami w odniesieniu do ich stabilności finansowej,

2) w sprawie wspólnych przepisów dotyczących monitorowania i oceny projektów planów budżetowych oraz zapewnienia korekty nadmiernego deficytu w państwach członkowskich należących do strefy euro.

${ }^{1}$ Są to: [Rozporządzenie Parlamentu Europejskiego i Rady (UE) nr 1175/2011..., 2011; Rozporządzenie Parlamentu Europejskiego i Rady (UE) nr 1173/2011..., 2011; Rozporządzenie Rady (UE) nr 1177/2011..., 2011; Rozporządzenie Parlamentu Europejskiego i Rady (UE) nr 1176/2011..., 2011; Rozporządzenie Parlamentu Europejskiego i Rady (UE) nr 1174/2011..., 2011; Dyrektywa Rady 2011/85/UE..., 2011].

${ }^{2}$ Należy tu wymienić: [Rozporządzenie Parlamentu Europejskiego i Rady (UE) nr 472/2013..., 2013; Rozporządzenie Parlamentu Europejskiego i Rady (UE) nr 473/2013]. 
Przedstawione powyżej przepisy Unii Europejskiej miały służyć wzmocnieniu koordynacji polityki gospodarczej w strefie euro, gdyż problemy jednego z krajów mogą zagrozić bezpieczeństwu finansowemu pozostałych krajów. Aby to osiągnąć, zwiększono monitoring polityki fiskalnej w krajach przeżywających trudności finansowe oraz ustalono wspólny harmonogram budżetowy dla krajów strefy euro. Poniżej podjęta zostanie próba oceny wpływu tych rozwiązań na sytuację krajów Unii Europejskiej w zakresie zadłużenia i nierównowagi budżetowej.

\section{Ocena poziomu i dynamiki zadłużenia krajów Unii Europejskiej}

Ocena sytuacji państw Unii Europejskiej pod względem zadłużenia i nierównowagi budżetowej została wykonana z wykorzystaniem metody wielowymiarowej analizy porównawczej TOPSIS. Metoda ta pozwala na zsyntetyzowanie wpływu na badane zjawisko wielu czynników. Wybrano tę metodę, gdyż według autora sam poziom długu publicznego nie jest w pełni miarodajnym wskaźnikiem do oceny sytuacji państw Wspólnoty w poruszanym zakresie. Do analizy wybrano więc zestaw czynników, które charakteryzują sytuację w zakresie zadłużenia i nierównowagi budżetowej. Należą do nich ${ }^{3}$ :

- dług publiczny (w \% PKB) - wyraża poziom zadłużenia publicznego w relacji do PKB, w związku z czym pozwala na porównanie poziomu zadłużenia pomiędzy krajami; jest on wielkością zasobową;

- poziom deficytu budżetowego (w \% PKB) - wyraża poziom nierównowagi fiskalnej sektora general government; jest to wielkość o charakterze strumieniowym i wskazuje na wzrost potrzeb pożyczkowych rządu;

- nadwyżka operacyjna (w \% PKB) - stanowi jeden z podstawowych wskaźników świadczących o wyniku budżetu bez uwzględnienia wpływu długu publicznego; wyraża on zdolność budżetu do sfinansowania pozostałych potrzeb finansowych;

- dynamika długu (w \%) - wskaźnik względny wskazujący na zmianę poziomu zadłużenia w stosunku do roku poprzedniego w stosunku do wielkości zadłużenia; wielkość tę wybrano, by wskazać, który kraj ma największe osiągnięcia w ograniczaniu poziomu zadłużenia lub kłopoty ze wzrostem poziomu zadłużenia;

- zmiana deficytu (w pkt. proc. PKB) - pokazuje kierunek i siłę zmian w poziomie nierównowagi fiskalnej sektora finansów publicznych; nie zdecydowano się na ocenę dynamiki deficytu, gdyż przy niskich wielkościach deficytu możliwe jest osiągnięcie bardzo wysokiej dynamiki, która w wartościach bezwzględnych będzie niewielka;

\footnotetext{
${ }^{3}$ Wartości zmiennych zostały pozyskane z bazy danych Eurostatu: https://ec.europa.eu/eurostat/ data/database (28.04.2018).
} 
- poziom stóp procentowych długoterminowych (w \%) - wyraża ocenę stabilności fiskalnej danego kraju przez rynki finansowe, gdyż w cenie pieniądza uwzględniona jest m.in. premia za ryzyko pożyczania pieniędzy danemu krajowi;

- wysokość płaconych odsetek od długu w skali roku (w \% PKB) - odzwierciedla ciężar, jakim dla budżetu państwa jest obsługa zadłużenia.

Powyższe zmienne zostały zweryfikowane pod kątem ich zmienności i skorelowania ze sobą. Zestawione wartości poszczególnych wskaźników zostały znormalizowane z uwzględnieniem odmiennego charakteru poszczególnych zmiennych (stymulanty, destymulany, nominanty). Następnie wyznaczone zostały odległości euklidesowe poszczególnych państw od wzorca i antywzorca. Na tej podstawie skonstruowany został miernik syntetyczny oceny zadłużenia i nierównowagi budżetowej poszczególnych krajów. Analizie został poddany okres 2010-2017. Od czasu wdrożenia pierwszych rozwiązań minęło więc 7 lat i okres ten pozwala na wyciągnięcie pierwszych wniosków. Otrzymane wyniki zaprezentowano w tab. 1.

Tabela 1. Wartość miernika syntetycznego zadłużenia i nierównowagi budżetowej krajów Unii Europejskiej

\begin{tabular}{|l|c|c|c|c|c|c|c|c|}
\hline \multicolumn{1}{|c|}{ Państwo } & 2010 & 2011 & 2012 & 2013 & 2014 & 2015 & 2016 & 2017 \\
\hline \multicolumn{1}{|c|}{1} & 2 & 3 & 4 & 5 & 6 & 7 & 8 & 9 \\
\hline Austria & 0,632 & 0,558 & 0,661 & 0,714 & 0,618 & 0,561 & 0,576 & 0,642 \\
\hline Belgia & 0,618 & 0,486 & 0,577 & 0,653 & 0,552 & 0,486 & 0,537 & 0,559 \\
\hline Bułgaria & 0,722 & 0,636 & 0,780 & 0,787 & 0,424 & 0,635 & 0,554 & 0,803 \\
\hline Chorwacja & 0,564 & 0,426 & 0,583 & 0,494 & 0,533 & 0,448 & 0,587 & 0,551 \\
\hline Cypr & 0,671 & 0,423 & 0,506 & 0,331 & 0,540 & 0,476 & 0,496 & 0,640 \\
\hline Czechy & 0,708 & 0,592 & 0,664 & 0,797 & 0,738 & 0,673 & 0,821 & 0,710 \\
\hline Dania & 0,683 & 0,593 & 0,706 & 0,808 & 0,769 & 0,636 & 0,786 & 0,745 \\
\hline Estonia & 0,935 & 0,865 & 0,655 & 0,843 & 0,853 & 0,684 & 0,741 & 0,746 \\
\hline Finlandia & 0,640 & 0,619 & 0,654 & 0,727 & 0,664 & 0,517 & 0,643 & 0,628 \\
\hline Francja & 0,653 & 0,511 & 0,605 & 0,671 & 0,589 & 0,482 & 0,530 & 0,486 \\
\hline Grecja & 0,329 & 0,217 & 0,427 & 0,323 & 0,443 & 0,317 & 0,346 & 0,318 \\
\hline Hiszpania & 0,643 & 0,398 & 0,448 & 0,526 & 0,563 & 0,467 & 0,511 & 0,474 \\
\hline Holandia & 0,696 & 0,555 & 0,665 & 0,748 & 0,688 & 0,669 & 0,787 & 0,796 \\
\hline Irlandia & 0,344 & 0,226 & 0,448 & 0,583 & 0,662 & 0,693 & 0,697 & 0,647 \\
\hline Litwa & 0,571 & 0,499 & 0,688 & 0,756 & 0,710 & 0,544 & 0,766 & 0,611 \\
\hline Luksemburg & 0,655 & 0,744 & 0,755 & 0,847 & 0,814 & 0,704 & 0,839 & 0,618 \\
\hline Łotwa & 0,515 & 0,600 & 0,747 & 0,791 & 0,695 & 0,689 & 0,563 & 0,531 \\
\hline Malta & 0,651 & 0,523 & 0,625 & 0,663 & 0,637 & 0,576 & 0,709 & 0,728 \\
\hline Niemcy & 0,526 & 0,602 & 0,720 & 0,765 & 0,774 & 0,699 & 0,745 & 0,724 \\
\hline Polska & 0,625 & 0,536 & 0,662 & 0,666 & 0,687 & 0,516 & 0,489 & 0,593 \\
\hline Portugalia & 0,484 & 0,300 & 0,413 & 0,496 & 0,396 & 0,320 & 0,324 & 0,362 \\
\hline Rumunia & 0,561 & 0,484 & 0,663 & 0,703 & 0,635 & 0,572 & 0,501 & 0,518 \\
\hline
\end{tabular}




\begin{tabular}{|l|c|c|c|c|c|c|c|c|}
\hline \multicolumn{1}{|c|}{1} & 2 & 3 & 4 & 5 & 6 & 7 & 8 & 9 \\
\hline Słowacja & 0,669 & 0,546 & 0,607 & 0,703 & 0,678 & 0,571 & 0,627 & 0,600 \\
\hline Słowenia & 0,699 & 0,441 & 0,627 & 0,317 & 0,504 & 0,438 & 0,634 & 0,605 \\
\hline Szwecja & 0,836 & 0,660 & 0,656 & 0,738 & 0,664 & 0,700 & 0,855 & 0,710 \\
\hline Węgry & 0,541 & 0,451 & 0,598 & 0,586 & 0,492 & 0,437 & 0,472 & 0,408 \\
\hline Wielka Brytania & 0,526 & 0,473 & 0,564 & 0,677 & 0,553 & 0,438 & 0,521 & 0,486 \\
\hline Włochy & 0,558 & 0,439 & 0,504 & 0,513 & 0,454 & 0,400 & 0,421 & 0,376 \\
\hline Unia Europejska & 0,595 & 0,503 & 0,607 & 0,666 & 0,609 & 0,535 & 0,580 & 0,560 \\
\hline Strefa euro & 0,593 & 0,505 & 0,603 & 0,658 & 0,612 & 0,546 & 0,582 & 0,569 \\
\hline
\end{tabular}

Objaśnienia: im wyższa wartość miernika, tym kondycja państwa w zakresie zadłużenia i niezrównoważenia budżetu jest lepsza, wartość nie jest interpretowana bezpośrednio.

Źródło: opracowanie własne na podstawie wyników otrzymanych metodą TOPSIS.

Analiza otrzymanych wyników wskazuje na kilka faktów. Ocena wartości miernika syntetycznego dla całej Unii Europejskiej (wykres na rys. 1) oraz strefy euro ukazuje, że w analizowanym okresie sytuacja w zakresie zadłużenia i nierównowagi budżetowej nie uległa znaczącej poprawie. W roku 2011 można zaobserwować wyraźne pogorszenie się wartości miernika syntetycznego, co jest konsekwencją problemów kilku krajów strefy euro w okresie kryzysu zadłużeniowego oraz obniżenia zaufania inwestorów finansowych. Wartość miernika spadła z 0,60 do 0,50 . Po wdrożeniu pierwszych reform w latach 2012 i 2013 sytuacja zaczęła się poprawiać. Wartość miernika wzrosła, osiągając odpowiednio wartości 0,60 i 0,66. Jednak już w latach 2014 i 2015 ponownie się pogorszyła. Wartość miernika spadła do 0,61 i 0,54. Wynikało to z kolejnej fali spowolnienia gospodarczego w krajach objętych programami oszczędnościowymi. Ostatnie dwa lata poddane analizie to kolejne wahania miernika syntetycznego. Wartości miernika dla całej Unii Europejskiej i dla strefy euro okazały się zbliżone. Może to wynikać z dużego udziału tych krajów w całości Wspólnoty, choć problemy związane z deficytem dotknęły przede wszystkim członków strefy euro. Jednak sytuacja państw należących do Unii Gospodarczej i Walutowej była zróżnicowana. W części krajów sytuacja znacznie się pogarszała, podczas gdy w innych poprawiała.

Analiza wartości miernika dla poszczególnych krajów wskazuje, że pomiędzy nimi występują bardzo duże rozbieżności, choć kierunek zmian zwykle jest podobny. Najlepszą średnią wartością miernika syntetycznego (w przedziale $0,7-0,8$ ) wykazały się Estonia, Luksemburg, Szwecja, Dania, Czechy, Holandia i Niemcy. Najsłabszymi wartościami średnimi (w przedziale 0,3-0,5) charakteryzowały się Grecja, Portugalia, Włochy i Węgry. Nieco tylko lepszą sytuacją (średnio) wykazały się Cypr i Hiszpania. Największą poprawę wskaźnika zanotowała Irlandia, która po kryzysie z lat 2010-2011 (wynikającej ze wsparcia udzielonego sektorowi bankowemu) poprawiła wartość miernika o niemal 0,5 jednostki. Szczegółowa analiza ukazuje, że kraj ten konsekwentnie poprawiał swoją sytuację. Dług publiczny Irlandia obniżyła 
o $43 \%$, koszty obsługi długu spadły o 53\%, deficyt budżetowy spadł z 32\% PKB w 2010 roku do 0,3\% PKB w 2017 roku. Pozostałe wskaźniki także wyraźnie się poprawiały. Wśród liderów należy wskazać również Słowenię i Bułgarię (ten drugi kraj jest jednym z liderów w zakresie zadłużenia i zrównoważenia finansów publicznych); także Cypr po kryzysie zaczął poprawiać swoją sytuację. Z kolei w przypadku największego dłużnika, Grecji, poprawa sytuacji jest minimalna i wynika głównie $\mathrm{z}$ umorzenia części długu.

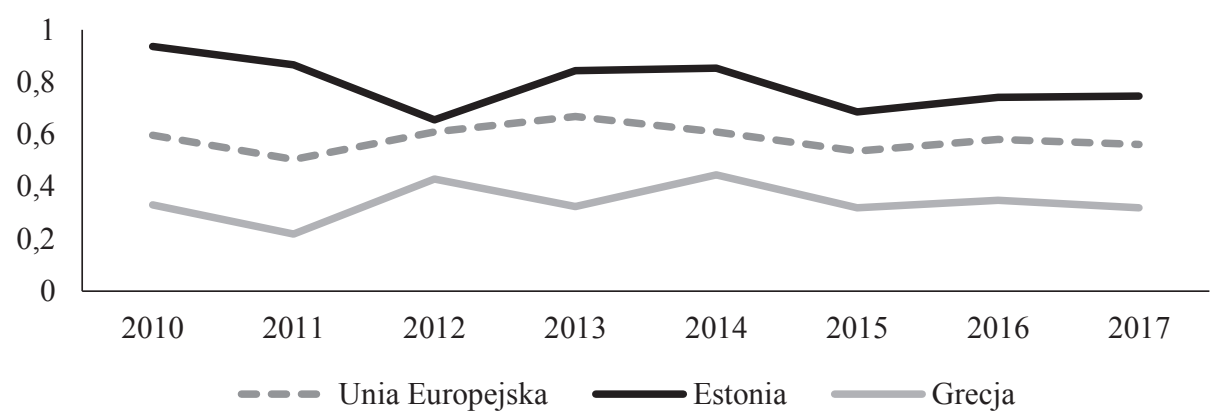

Rys. 1. Miernik syntetyczny zadłużenia i nierównowagi budżetowej dla Unii Europejskiej, najlepszego (Estonia) i najgorszego (Grecja) kraju pod względem średniej miernika syntetycznego $\mathrm{z}$ analizowanego okresu

Źródło: opracowanie własne na podstawie wyników metody TOPSIS.

W całym analizowanym okresie sytuacja poprawiła się w 10 krajach Wspólnoty. Szczególnie wyróżniają się tu Irlandia (wzrost o 0,3 jednostki) i Niemcy (o 0,2 jednostki). Ich sytuacja poprawiła się w największym stopniu. W pozostałych państwach wartość miernika pogorszyła się w stosunku do 2010 roku. Szczególnie wyraźnie (o 0,15-0,2 jednostki) spadła dla Węgier, Francji, Hiszpanii, Włoch i Estonii. Jednak we wszystkich państwach widać wyraźne jego wahania. Największy współczynnik zmienności (powyżej 20\%) dla miary syntetycznej miały Irlandia, Słowenia, Cypr i Grecja. Wartość niższą niż 10\% miały jedynie Finlandia, Słowacja i Austria. Co ciekawe, współczynnik zmienności dla całej Unii Europejskiej i strefy euro wyniosły odpowiednio jedynie 8,63 i 7,83\%. Można to przypisać kompensowaniu negatywnych zmian w jednych krajach pozytywnymi zmianami w innych.

\section{Podsumowanie}

Podsumowując, przeprowadzona analiza wskazuje, że sytuacja Unii Europejskiej i poszczególnych krajów członkowskich w zakresie zadłużenia i nierównowagi budżetowej po uchwaleniu i wdrożeniu pakietów rozporządzeń i dyrektyw nie poprawiła się w znaczący sposób. Zdecydowane działania podjęte po kryzysie zmierzały do poprawy dyscypliny budżetowej, przejrzystości finansów publicznych i koordynacji polityk go- 
spodarczych. Przeprowadzona analiza wykazała, że występują przykłady krajów, które z powodzeniem poprawiły swoją sytuację budżetową. Są to jednak wyłącznie pojedyncze przykłady krajów (np. Irlandii). W państwach o największych problemach poprawa jest jedynie częściowa. Źródeł tego faktu należy upatrywać w braku konsekwencji we wdrażaniu reform i uzależnieniu ich skuteczności od decyzji poszczególnych rządów. Należy jednak również podkreślić, że na sytuację tę miały również wpływ czynniki zewnętrzne, takie jak wahania koniunktury globalnej. Dlatego też wątpliwości budzi dalsza skuteczność pakietu działań Unii Europejskiej, które miały poprawić równowagę budżetową, obniżyć poziom zadłużenia oraz zapewnić stabilizację makroekonomiczną.

\section{Literatura}

Alesina A.F., Favero C.A., Giavazzi F., 2012, The output effect of fiscal consolidations, CEPR Discussion Papers 9105.

Alt J.E., Lassen D.D., 2006, Fiscal transparency, political parties, and debt in OECD countries, European Economic Review, 50, s. 1403-1439.

Balcerzak A.P., Pietrzak M.B., Rogalska E., 2014, Niekeynesowskie skutki polityki fiskalnej w krajach strefy euro, ze szczególnym uwzględnieniem wpływu na proces konwergencji gospodarczej, Przegląd Statystyczny, z. 4.

Baldacci E., Gupta S., Mulas-Granados C., 2015, Debt Reduction, Fiscal Adjustment, and Growth in Credit-Constrained Economies, Journal of Applied Economics, vol. XVIII, no. 1, 71-98.

Baza danych Eurostatu, https://ec.europa.eu/eurostat/data/database (28.04.2018).

Daniel J., Davis J., Fouad M., Van Rijckeghem C., 2006, Fiscal Adjustment for Stability and Growth, International Monetary Fund, Washington, D.C.

Das U.S., Papapioannou M., Pedras G., Ahmed F., Surti J., 2010, Managing Public Debt and Its Financial Stability Implications, IMF Working Paper, 10 (280).

Dyrektywa Rady 2011/85/UE z dnia 8 listopada 2011 r. w sprawie wymogów dla ram budżetowych państw członkowskich, Dz. Urz. UE L 306/41 z 23.11.2011.

Fatás A., Summers L.H., 2018, The permanent effects of fiscal consolidations, Journal of International Economics, iss. 112, https://doi.org/10.1016/j.jinteco.2017.11.007.

Groneck M. 2010, A golden rule of public finance or a fixed deficit regime? Growth and welfare effects of budget rules, Economic Modelling 27

Kopits G., 2011, Independent Fiscal Institutions: Developing Good Practices, OECD Journal on Budgeting, vol. 3.

Maltritz D., Wüste S., 2015, Determinants of budget deficits in Europe: The role and relations of fiscal rules, fiscal councils, creative accounting and the Euro, Economic Modelling, vol. 48.

Nickel C., Rother P., Zimmermann L., 2010, Major public debt reductions: Lessons from the past, lessons for the future, Working Paper Series 1241, European Central Bank.

OECD, 2011, Restoring Public Finances, OECD Publishing, Paris.

Postuła M., 2014, Konsolidacja fiskalna w trakcie prac nad corocznym budżetem państwa, Oeconomia Copernicana 2014, vol. 5, iss. 1.

Rozporządzenie Parlamentu Europejskiego i Rady (UE) nr 472/2013 z dnia 21 maja 2013 r. w sprawie wzmocnienia nadzoru gospodarczego i budżetowego nad państwami członkowskimi należącymi do strefy euro dotkniętymi lub zagrożonymi poważnymi trudnościami w odniesieniu do ich stabilności finansowej, Dz. Urz. UE L 140 z 27.05.2013.

Rozporządzenie Parlamentu Europejskiego i Rady (UE) nr 473/2013 z dnia 21 maja 2013 r. w sprawie wspólnych przepisów dotyczących monitorowania i oceny projektów planów budżetowych 
oraz zapewnienia korekty nadmiernego deficytu w państwach członkowskich należących do strefy euro, Dz. Urz. UE L 140/11 z 27.05.2013.

Rozporządzenie Parlamentu Europejskiego i Rady (UE) nr 1173/2011 z dnia 16 listopada $2011 \mathrm{r}$. w sprawie skutecznego egzekwowania nadzoru budżetowego w strefie euro, Dz. Urz. UE L 306/1 z 23.11.2011.

Rozporządzenie Parlamentu Europejskiego i Rady (UE) nr 1174/2011 z dnia 16 listopada 2011 r. w sprawie środków egzekwowania korekty nadmiernych zakłóceń równowagi makroekonomicznej w strefie euro, Dz. Urz. UE L 306/8 z 23.11.2011.

Rozporządzenie Parlamentu Europejskiego i Rady (UE) nr 1175/2011 z dnia 16 listopada 2011 r., zmieniające rozporządzenie Rady (WE) nr 1466/97 w sprawie wzmocnienia nadzoru pozycji budżetowych oraz nadzoru i koordynacji polityk gospodarczych, Dz. Urz. UE L 306 z 23.11.2011.

Rozporządzenie Parlamentu Europejskiego i Rady (UE) nr 1176/2011 z dnia 16 listopada 2011 r. w sprawie zapobiegania zakłóceniom równowagi makroekonomicznej i ich korygowania, Dz. Urz. UE L 306/25 z 23.11.2011.

Rozporządzenie Rady (UE) nr 1177/2011 z dnia 8 listopada 2011 r. zmieniające rozporządzenie (WE) nr 1467/97 w sprawie przyspieszenia i wyjaśnienia procedury nadmiernego deficytu, Dz. Urz. UE L 306/33 z 23.11.2011.

Rzońca A., 2007, Czy Keynes się pomylit, Wydawnictwo Naukowe Scholar, Warszawa.

Rzońca A., 2004, Niekeynesowskie skutki zacieśnienia polityki fiskalnej. Zmodyfikowany model Blancharda, Część I, Bank i Kredyt, nr 10.

Stone J.A., 2016, Do balanced-budget rules increase growth?, Bulletin of Economic Research, 68(1).

Trzcińska A., 2013, Europejski Mechanizm Stabilności jako stabilizator w planowanej unii finansowej, https://www.nbp.pl/badania/seminaria/10iv2013.pdf (15.05.2018).

von Hagen J., Wolff G., 2006, What do deficits tell us about debt?: Empirical evidence on creative accounting with fiscal rules in the EU, Journal of Banking and Finance, 30 (12).

Yang W., Fidrmuc J., Ghosh S., 2015, Macroeconomic effects of fiscal adjustment: A tale of two approaches, Journal of International Money and Finance, iss. 57. http://dx.doi.org/10.1016/j.jimonfin.2015.05.003. 